$\xi=$

\title{
The Transformation of the System of Leasing Relations in the Real Economy Sector
}

\author{
Lubov Konstantinovna Ulibina ${ }^{1}$, Olga Alekseevna Okorokova ${ }^{1}$, Vladimir Sergeevich Lukashov ${ }^{1}$, Mikhail Gennade- \\ vich Rusetskiy ${ }^{2}$, Liliya Vasilievna Blizno \\ 1Kuban State Agrarian University (Kuban SAU), 13, Kalinina Street, Krasnodar, Russia, 350044 \\ 2North Caucasus Federal University (NCFU), 1, Pushkina Streel, Stavropol, Russia, 355009 \\ 3Stavropol Institute of Cooperation (Branch) Belgorod University of Cooperation, Economics and Law (BUKEP), 36, Goleneva Street, \\ Stavropol, Russia, 355000.
}

\begin{abstract}
The article presents the analysis of the leasing mechanism as one of the main ways to improve technical and technological processes of various sectors of economy of the country. In the conditions of economic crisis and stagnation in economy the leasing instrument can positively affect the investment demand and the economy of a separate region and of the country in general. The increasing demand for leasing and its wide distribution in all branches will contribute to increasing their technical equipment, improving technological processes which could enable to overcome disproportion in the development of different of branches of economy of the country. The perspectives of the development of the leasing market in the Russian Federation will depend on the formation of consumer demand and on the value of such services; such consumer demand will timely meet all macroeconomic needs. The main factors of preserving demand for leasing in the conditions of economic and political instability must include the development of leasing relations and the state support of the leasing instrument by means of its subsidising, the high level of depreciation of fixed assets and the necessity to modernise them.
\end{abstract}

Keywords: instrument, leasing, agroleasing, reproductive process, investments, agricultural producers, leasing portfolio, leasing fund.

\section{Introduction}

The strategic policy in the sphere of leasing must be coordinated with the investment and production policy of the Russian Federation that is based on the system of necessary organisational arrangements for the effective development of fixed assets in all the branches of economy and in agriculture in particular. The introduction of such a system will enable to increase the amount of quality and high-technology goods, thus, improving budget tax revenue. At the given stage it is appropriate to implement such activities as partial subsidising of expenses for leasing transactions both at the federal and regional levels, to strengthen leasing positions as one of the main instruments of modernising the material and technical basis of corporations, to improve the legal base of leasing activity, to develop the standards of leasing activity and self-regulating leasing institutions. It is also advisable to develop the secondary market of machinery and equipment, to create favourable conditions for promoting leasing in the sector of small and medium-sized businesses by means of complex support in all the directions such as informational, legal, financial and property ones, improving the system of tax levying in leasing activity through providing tax incentives for the participants of leasing relations.

\section{Leasing as an Instrument for Intensive Re- productive Process of the Fixed Assets in the Agro-Industrial Complex}

The agro-industrial complex is the biggest intersectoral structure of the Russian national economy including corporations connected with each other by economic relations in terms of production, distribution, exchange and consumption of agricultural products. Consequently, the role of reproduction and renewal of the material and technical basis and the agricultural equipment and tractor park of the agro-industrial complex cannot be underestimated while conducting agrarian reforms; special attention should be paid to these activities at the level of the state.

At the current stage of the development of the agro-industrial complex of the country the issue of renewal of the agricultural equipment, tractor park and other agricultural machines is quite urgent.

In the current situation many agricultural producers use the services of equipment renting offices for the period of field work. The payment for the rented equipment is very high in modern practice ranging from $15 \%$ to $35 \%$ of gross agricultural production. Long-term bank lending is not always an effective investment tool for credit institutions, as banks prefer to work primarily with major clients and agro-industrial holdings that have an impeccable reputation $[1,2]$.

In agriculture low profitability farms constitute a large group; it is extremely hard to take a loan. In this regard the necessity to search new sources of financing arises. The risks of long-term investments are the main factors restraining the development of regional 
lending of investment activities. Investment projects aimed at the development of the agro-industrial complex still lack reliable support, marketing and financial analysis adequate for modern market conditions and complete technical-economic justification.

The conceptual construct "agroleasing" has specific features resulting from sectoral and organizational factors that were singled out and specified in the process of the research. A revise set of features of leasing in the agro-industrial complex includes four groups of factors: economic, psychological, organisational and competitive ones (Fig.1)

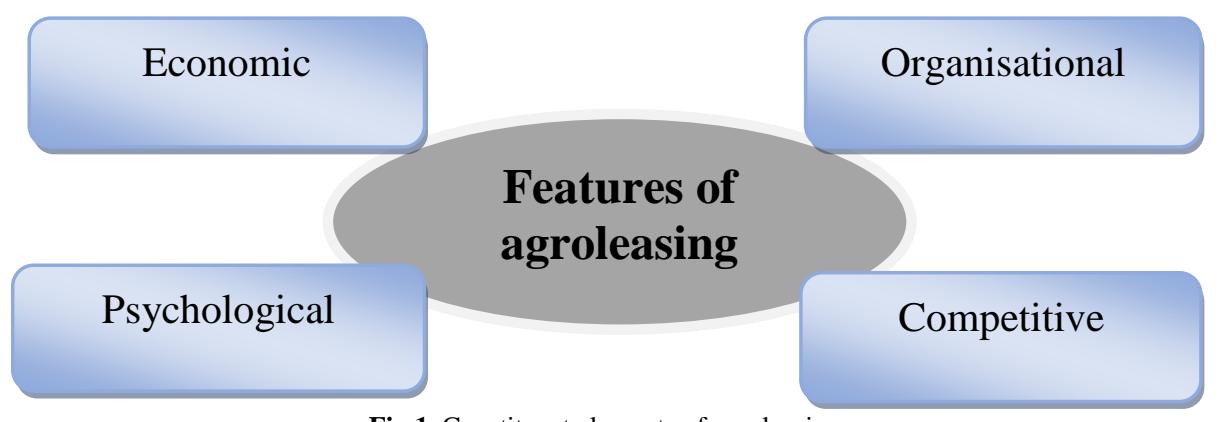

Fig.1. Constituent elements of agroleasing.

The fact that the state structures are present in agroleasing has not only advantages in the form of state support and benefits but also disadvantages associated with monopolisation and the inevitable bureaucratisation of all the processes. It makes organisational procedures more complicated and delays the process of settling leasing transactions.

State support, as a rule, regulates the list of material and technical resources, machines and equipment received in leasing which determines the presence of certain competitive features of agroleasing.

The mechanism to manage agroleasing in modern conditions is a complex of interconnected instruments and mechanisms (main and supplementary) the basis of which is an organisational-economic mechanism of the agro-industrial complex that in its turn is a multilevel hierarchical system. In forming the agricultural leasing, the following factors are of great importance: the justification of target indicators of the agro-industrial complex of a region and of Russia in general, the identification of internal resources and external opportunities for further development [3].

The implementation of the system of agroleasing must be carried out through a net of regional leasing companies, the selection of which is necessary to be conducted on a competitive basis and statistical ranking agencies. To provide healthy competition in a region it is essential to arrange four or five leasing companies.

Fig. 2 presents the dynamics of investments into the fixed capital of the agriculture of Krasnodar Krai.

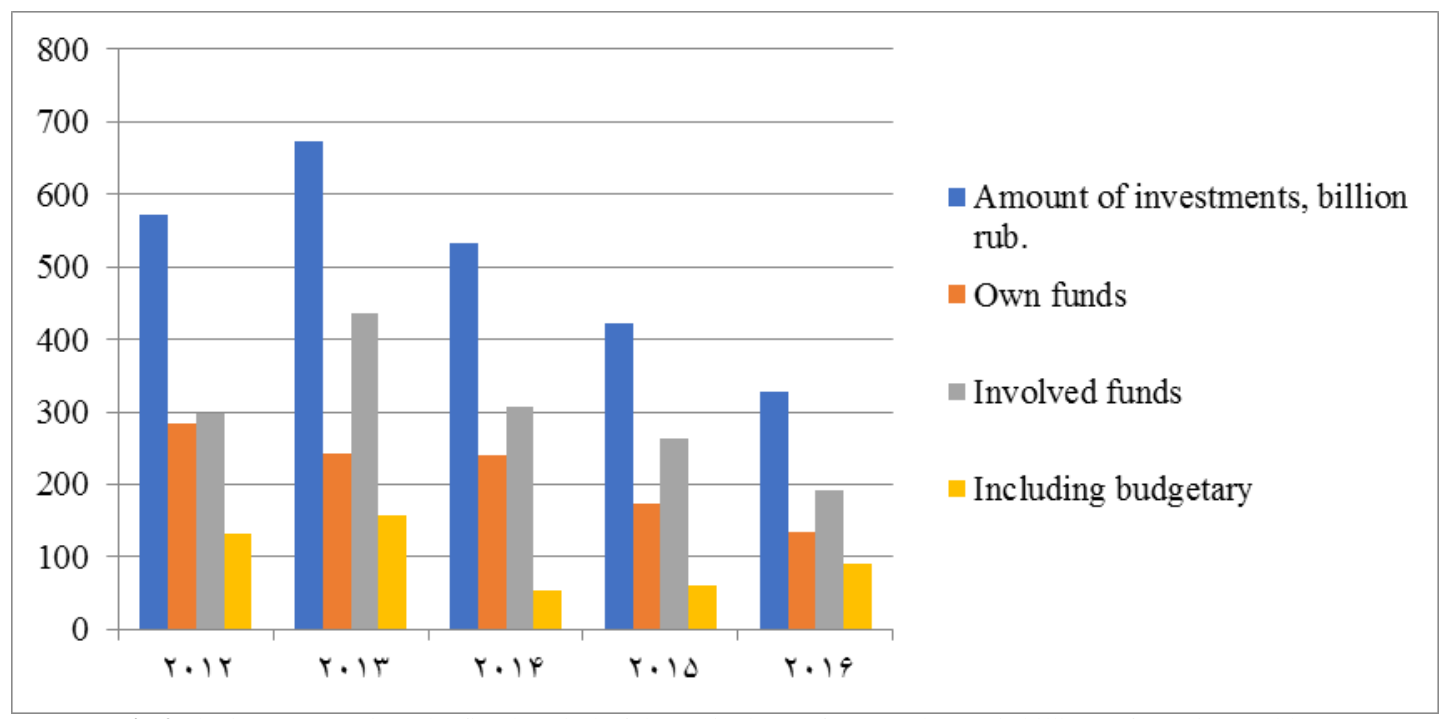

Fig.2. the investments into the fixed capital of the agriculture of Krasnodar Krai (billions of Russian roubles).

The current decreasing investments both in agriculture and in the economy of Russia in general are quite protracted. A sharp decline in investments occurred in 2016; compared to 2013 they dropped by almost $50 \%$. The fall can be seen if compared to the indicators of 2015, though it is less dramatic (23\%). The share of own funds of corporations in the structure of financing of the fixed capital in 2015-2016 was $41 \%$ from the total volume of investments. Such permanence existed against the background of decreasing borrowed funds but it was rather high $(62 \%-58 \%)$ compared to nominal volume in general. The government programmes to support and develop agriculture in Russia as well as the programmes of import substitution envisaged increased funding of all branches of the agro-industrial complex of the country from all sources of budget funds.

\section{Economic Potential of Leasing and Oppor- tunities to Implement the Mechanism of Re- newal of the Material and Technical Basis of the Country in the Conditions of Economic In- stability}

After studying the investments into the fixed capital in the Southern Federal District we can note that the investments into Krasnodar Krai constituted the biggest part in the total volume (Table 1). 
Table 1. The investments into the fixed capital in Russia (millions of Russian roubles) [3]

\begin{tabular}{|c|c|c|c|c|c|}
\hline Indicator & 2012 & 2013 & 2014 & 2015 & 2016 \\
\hline Investments in total & 12586.1 & 13450.2 & 13557.5 & 14005.0 & 14639.8 \\
\hline Investments into the agro-industrial complex & 476.4 & 516.6 & 503.0 & 538.1 & 611.2 \\
\hline The Southern Federal District & 1254958 & 1506034 & 1383658 & 1296200 & 1110446 \\
\hline Krasnodar Krai & 798476 & 955208 & 750236 & 586903 & 428972 \\
\hline Including investments into the agro-industrial complex & 29910.9 & 25437.1 & 28468.9 & 30035.3 & 37977.2 \\
\hline
\end{tabular}

The investments in Krasnodar Krai made 428972 million of Russian roubles that constitute $38.6 \%$ in the total structure of investments in the Southern Federal District. After analysing the volumes of financing in the agro-industrial complex it can be stated that investment sums are increasing and in 2016 made 37977.2 Russian roubles; there has been an increase by $127 \%$ compared to 2012. This fact is due to major investments to elaborate and develop complex infrastructure of the region and to create largescale manufacturers on the territory of Krasnodar krai both in agriculture and in processing industries in 2011-2013. The reduced financing compared to 2012 constituted $46.3 \%$ [4].
According to the data presented by the Bank of Russia, the leasing portfolio made approximately $10 \%$ from the total volume of loans granted for corporate clients that proves the fact that the development of leasing relations in Russia are on the start-up phase and it requires to be further supported and improved by the government. After considering the quality of the leasing portfolio we can note that it is at an acceptable level and constituted $4.8 \%$ from the share of overdue debts in the leasing portfolio.

Fig. 3 presents the structure of leasing contract sums in transaction size in the Russian Federation.

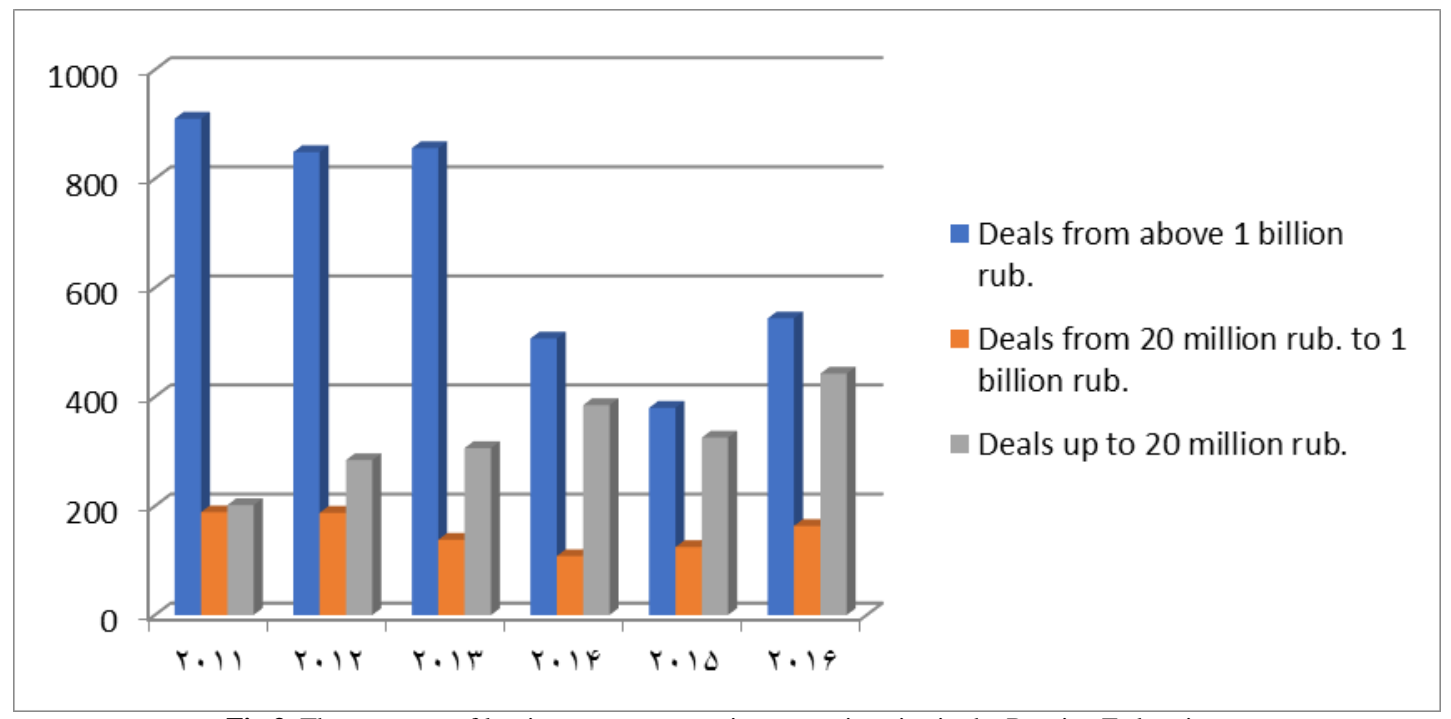

Fig.3. The structure of leasing contract sums in transaction size in the Russian Federation.

Conducting transactions over 1 billion Russian roubles by leasing companies enabled to increase the volume of the leasing portfolio by $39 \%$ in 2016 that made 1.2 trillion Russian roubles.

Leasing contracts measuring from 20 million to 1 billion of Russian roubles that were mainly concluded by medium-sized enterprises and government establishments demonstrate positive dy- namics for the second consecutive year; however, they are still smaller in volume than both major and minor transactions. At the same time an average sum of a transaction on the market increased from 6.7 to 8.2 million Russian roubles in 2016 that was resulted from singing major contracts in the end of the year (Fig.4).

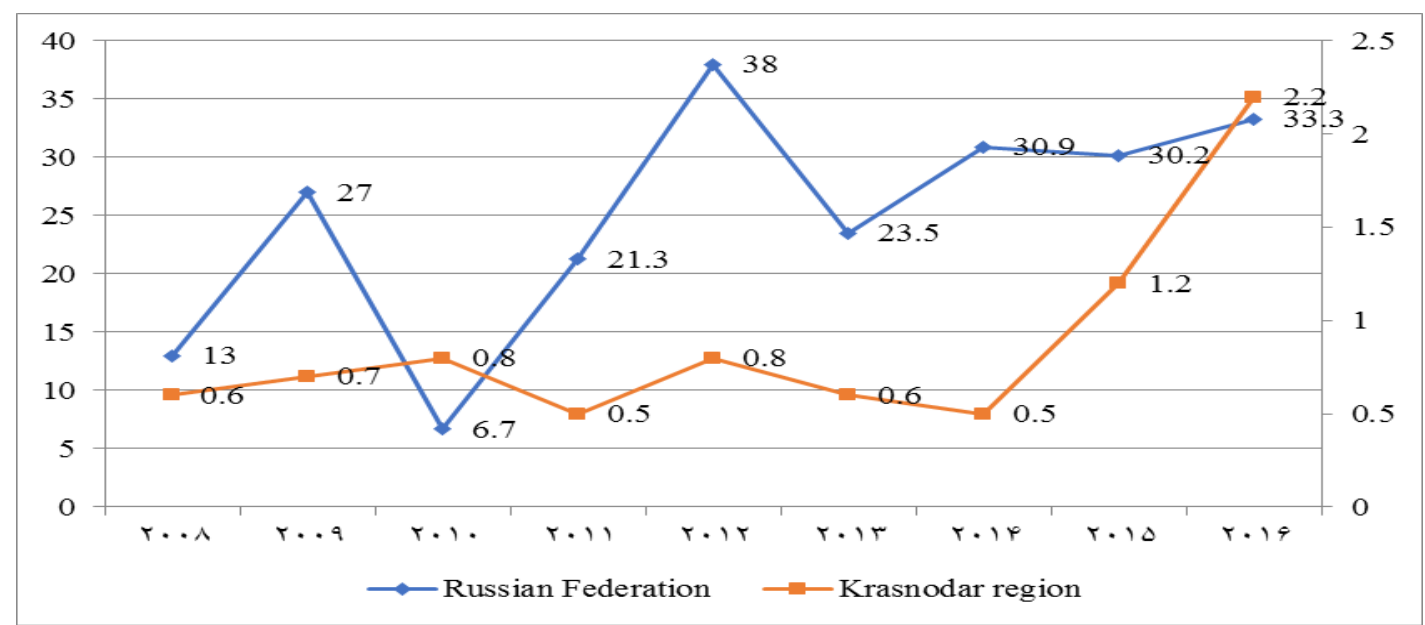

Fig.4. The amount of agroleasing in the Russian Federation and in Krasnodar Krai (billions of Russian roubles).

The amount of leasing contract totalled 1.2 trillion Russian roubles in 2016 and increased by $39 \%$ in 2015 . The leasing portfolio ceased stagnating and made 3.2 trillion Russian roubles in 2016 , in 205 this indicator was 3.1 trillion Russian roubles, in spite of 
record volume of leasing payments received in the previous year [5].

It is worth noting that for the first time since 2013 the share of leasing transactions in the GDP of Russia against the background of its reduction reached $1.2 \%$; last time such a tendency could be seen in 2011-2013 before the financial crisis. The volume of funded assets in 2016 demonstrated positive growth dynamics and totalled $25 \%$ which could be seen previously in 2013 on the market. The share of the biggest lessor in the amount of new business almost reached $17 \%$ in 2016 (in 2015 it was $14 \%$, in 2014 it was $16 \%)$. The top 10 companies' concentration in the volume of new business reduced and made $63 \%$ in accordance with the results of 2016; in 2015 it was 67\%; in 2014 it was 64\% (Table 2).

Table 2. Top 10 leasing companies in the volume of new business in 2016.

\begin{tabular}{|c|c|c|c|}
\hline $\begin{array}{c}\text { Ranking } \\
\text { place }\end{array}$ & Name of a company & $\begin{array}{c}\text { Volume of new business (millions of Russian } \\
\text { roubles) }\end{array}$ & $\begin{array}{c}\text { Sum of new leasing contracts (millions of Russian } \\
\text { roubles) }\end{array}$ \\
\hline 1 & $\begin{array}{c}\text { State Transport Leasing Com- } \\
\text { pany }\end{array}$ & 122753.2 & 188332.9 \\
\hline 2 & Sberbank Leasing & 82871.4 & 125655.9 \\
\hline 3 & VTB Leasing & 76658.4 & 114744.3 \\
\hline 4 & Europlan & 37950.6 & 44715.9 \\
\hline 5 & VEB-leasing & 33570.6 & 49303.2 \\
\hline 6 & Siemens & 27232.6 & 43021.3 \\
\hline 7 & Baltic Leasing & 23938.0 & 35785.0 \\
\hline 8 & CBM-leasing & 22948.0 & 31514.0 \\
\hline 9 & Gazprombank Leasing & 20325.0 & \\
\hline 10 & TransFin-M & 18849.4 & \\
\hline 11 & Rosagroleasing & 16712.0 & \\
\hline
\end{tabular}

In accordance with the results of 2016 the share of leasing state companies in the volume of new business made 51\%, in 2015 it was $53 \%$. The increase in transactions by private leasing companies including the lessors at banks and manufacturers became the reason of the decrease in the concentration of leasing business on state companies $[3,6,7]$.

The amount of the segment of agricultural machines increased 1.8 times and its share on the market made 3\%. Retail market players in the sphere of leasing services in 2016 noted a growing demand for leasing on the part of agricultural companies due to increasing volumes of their sales; reduced competition on the part of foreign manufacturers served as another reason to that. The programmes of the development and the amount of state support of agriculture is determined individually for each region; $70 \%$ of down payment is subsidised for Krasnodar Krai but no more than $30 \%$ from the cost of machines and equipment. Subsidising the agricultural manufacturers of the region is carried out within the regional target programme "State support of small and medium-sized enterprises in Krasnodar Krai for 2013-2017" [8].

The most important indicator for assessing the financial condition of leasing companies is the adequacy of own funds and the sensitivity for large credit risks, as the practice of providing leasing for large customers is rather common $[9,10,11,12]$.

The credit quality of the leasing portfolio is sufficient: in 2016 the share of overdue debt on leasing transactions was $4.75 \%$, in the banking sector this indicator was $10.7 \%$. Total assets of low quality in the investment portfolio of leasing companies in 2016 amounted to 76.7 billion Russian roubles with leasing contracts overdue for more than 90 days.

The monitoring and mitigating risks requires the analysis of certain indicators such as adequacy of own capital, liquidity, concentration risk and currency position [13, 14].

The systematic influence on the financial system and nonfinancial sector of economy is connected with the "contamination" effect which requires from leasing companies to attract credit resources in order to finance their activity; at the same time leasing is a driver of credit cycle in a number of branches of the country's economy $[15,16]$.

To implement the given programme it is necessary to solve the following issues: to improve the forms of participation of small economy subjects in the total turnover of business entities of Krasnodar Krai; to introduce the mechanisms of soft loans and financial support of small and medium-sized enterprises; to develop instruments of financial support of small and medium-sized enterprises. For Krasnodar Krai the maximum possible limit of subsidy provided for a single subject within the framework of implementing the programme of state support of small and medi- um-sized enterprises cannot exceed 15 million Russian roubles during one fiscal year.

Financing the agro-industrial complex of Russia from budget resources is impossible due to limited financial resources of the country and cannot be carried out in the near term; however, it would enable to solve the majority of problems in agriculture. Therefore, at present establishing commercial leasing with state participation, the so-called leasing with state-private partnership is quite relevant [8]. Leasing based on state-private partnership can currently be considered as one of perspective programmes of the development of the agro-industrial complex of Russia and agroleasing in particular. It will become essential from the standpoint of demonopolisation of the system of agroleasing established in the country and in terms of creating competitive market in the agro-industrial complex leasing. The system changes of modernising the economy at the present stage are impossible to be introduced without structural revision of the current scheme of financing agricultural manufacturers [17].

\section{Applying Leasing Instrument as a Mecha- nism to Invest into the Real Sector of the EAEU Economy}

The leasing relations market in the EAEU countries is characterised by the main trends and features of the European leasing market as well. With reducing profitability of leasing business, with further strengthening of major leasing players and with their geographic expansion the development of the leasing instrument for small and medium-sized enterprises as a key element of making efforts becomes the main supporting point $[18,19]$.

The development of the leasing services market in Belarus and Kazakhstan is at the initial stage, its active and widespread improvement and support from the state are necessary. According to sources of financing, $50.1 \%$ of leasing items were purchased through own funds, $49.9 \%$ were obtained through borrowed funds. The average amount of advanced payments totalled $18.7 \%$ (Table $3)$. 
Table 3. Main indicators of the EAEU leasing market in 2011-2016.

\begin{tabular}{|c|c|c|c|c|c|c|}
\hline Indicator & 2011 & 2012 & 2013 & 2014 & 2015 & 2016 \\
\hline \multicolumn{7}{|c|}{ The Republic of Belarus } \\
\hline The volume of the leasing portfolio (billions Belarusian roubles) & 10974 & 16137 & 17908 & 19602 & 25955 & $2589 *$ \\
\hline The share in the GDP of the county $(\%)$ & 2.5 & 2.0 & 1.7 & 1.65 & 1.28 & 1.5 \\
\hline \multicolumn{7}{|c|}{$\begin{array}{ll} & \text { The Republic of Kazakhstan } \\
\end{array}$} \\
\hline The volume of the leasing portfolio (millions Kazakhstani tenge) & 143466 & 170925 & 192537 & 198810 & 256326 & 298180 \\
\hline $\begin{array}{l}\text { GDP } \\
\text { (billions Kazakhstani tenge) }\end{array}$ & 27572 & 32194 & 37085 & 40755 & 40878 & 46190 \\
\hline
\end{tabular}

The leasing portfolio in 2016 amounted to 2589 million Belarusian roubles; there are 178372 active leasing contracts, which is three times higher than in 2015. In the last two years the demand for investment into fixed assets is decreasing which is proved by the decrease in the share of machinery and equipment. The market value of credit resources is higher than the profitability of Belarusian enterprises. The borrowed funds provided for financing the new businesses amounted to almost $70 \%$ of a freely convertible currency. 2016 witnessed a sharp increase in consumer leasing. Consumer leasing has become a new direction in the financial services market in the Republic of Belarus [20].

Having studied the leasing market in the Republic of Kazakhstan, we can claim that it faces the consequences of devaluation of the national currency and an economic slowdown which against the general backdrop affects concluding leasing contracts in the country. "KazAgroFinance" is a leader in the Kazakhstan leasing sphere with the share of $57 \%$ of new businesses from the total amount of the leasing portfolio in 2016. Leasing, which actively finances various branches of the Kazakhstan economy and expanses the scope of its activities, is a perspective direction of the development of the agrarian sector of the national economy.

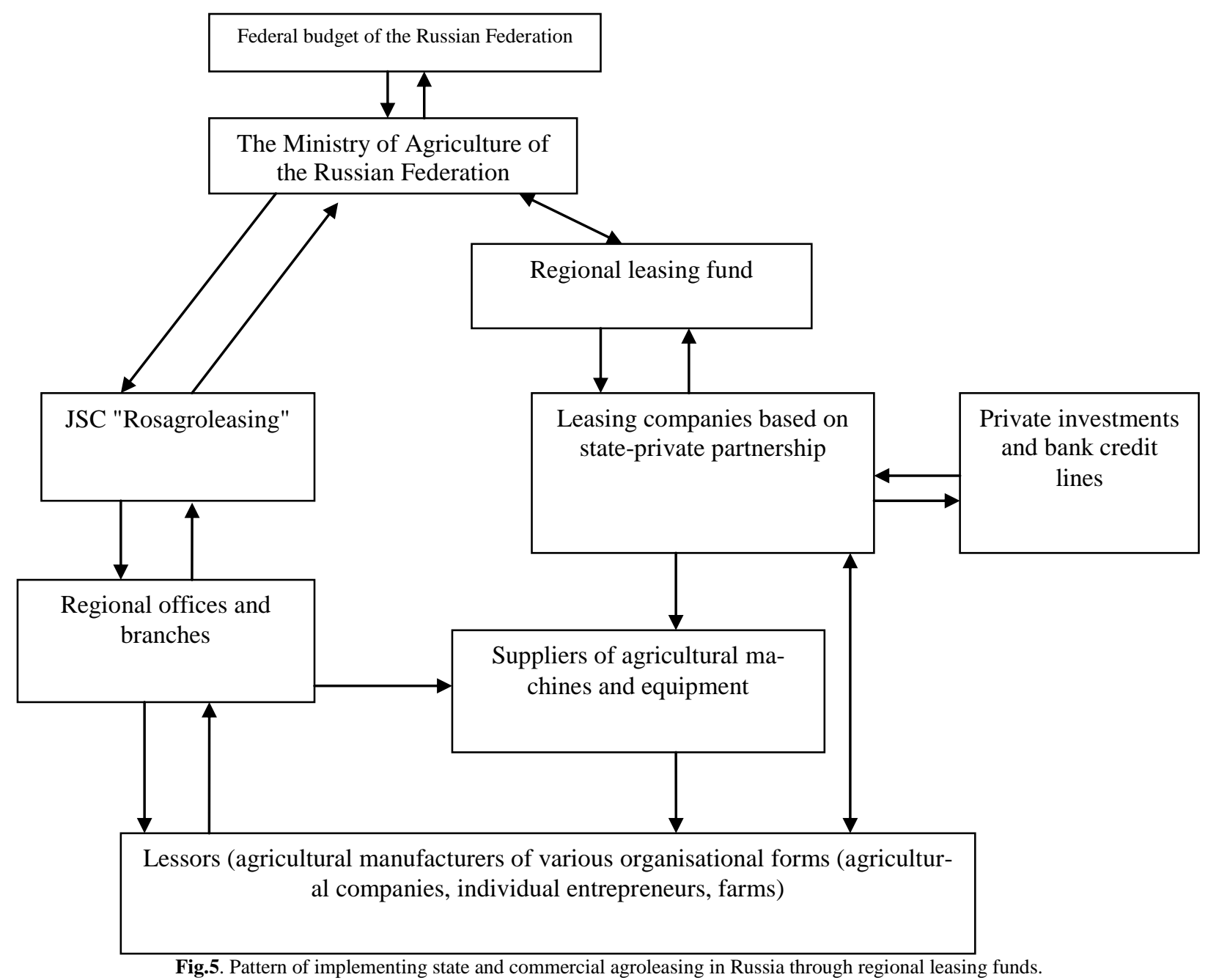

Fig.5. Pattern of implementing state and commercial agroleasing in Russia through regional leasing funds.
The share of agricultural machines and equipment in the structure of investments of leasing contracts decreased from $61.1 \%$ to $41.7 \%$. The change in the structure of new transactions is the direct consequence of redistribution of market shares of the two biggest leasing companies with state participation that provide the main leasing financing of the most significant economy branches. The volume of leasing contracts totalled 166.7 billion Kazakhstani tenge in 2016 with 6.5 thousand concluded contracts. An average value of a single leasing contract was 25.7 million Kazakhstani tenge. The demand for purchasing agricultural machines and equipment though the leasing mechanisms increased by $4 \%$. JSC "KazAgroFinance" is the main player in agroleasing [21].

After analysing the agroleasing market in Russia and after considering the main indicators of the EAEU leasing market we can present a pattern of implementing state and commercial agroleasing in Russia through regional leasing funds (Fig.5). 


\section{The Perspective Pattern of Implementing Leasing Relations between the Subjects of the Sgro-Industrial Complex in Russia}

One of the main perspective vectors of the development of JSC "Rosagroleasing" in Russia is the establishment of offices and branches in federal districts, namely, in Krasnodar Krai, Rostov Oblast, Stavropol Krai, Volgograd Oblast and other regions of the country with a high share of agriculture in the regional production output. These departments will independently form and use the amounts and sums of contracts concluded in accordance with the allocated quotas. The given system will contribute to developing leasing relations on the market following three competitive directions: leasing companies for clients, suppliers of agricultural machines and equipment and credit institutions. The presented infrastructural changes will allow promoting competitive environment in the sphere of agricultural leasing as well as diversifying the sources of financing leasing projects. The opportunity to use state funds will stimulate banks to take an active part in financing leasing transactions which will enable to create and implement the leasing mechanism with state-private partnership [3, 22, 23, 24].

\section{Conclusion}

The leasing services market is developing in the conditions of stagnating Russian economy and in unstable economic relations. Leasing as one of the main available instruments of modernising the fixed assets of corporations will continue its development in the segment of small and medium-sized enterprises. The leading factors of the growing amount of the leasing relations are as follows: the growing volume of small and medium-sized entrepreneurship in terms of technical and technological modernisation; rapid development of leasing companies compared to the segment of crediting; state support of leasing for small and medium-sized enterprises; decline in the proportion of major transactions in bank crediting and refusal to lend to subjects of small and mediumsized enterprises and their reorientation on leasing services.

The development of big business in the leasing segment will become an effective investment instrument including complete transaction support and post-warranty service.

\section{Acknowledgments}

The authors express their deep appreciation to S. Gatti, A. Meidan, G. Sharma, V.D. Gazman, V.V. Kovalev, V.A. Burenin, the authors of theoretical and methodological researches on the leasing sphere and on its development as an investment instrument.

\section{References}

[1] Meidan, Strategic problems in international leasing, Management International Review 24(4) (1990) 36-47.

[2] G. Sharma, An assignment on features and working of leasing industry of Germany, National Law University, Joghpur, 2012.

[3] L.K. Ulybina, Leasing as an alternative instrument of investmen into the country's economy, Economics and entrepreneurship 12 2(65-2) (2015) 117-121

[4] O.A. Okorokova, Problems and perspectives of the leasing development in Russia, A collection of articles: Scientificmethodological and social aspects of psychology and pedagogy, 2016.

[5] V.S. Lukashov, The leasing mechanism as an instrument to invest into the real sector of economy, Economic Sciences 1(146) (2017) 77-82.

[6] V.V. Kovalev, Leasing. Financial, accounting-analytical and legal aspects, Prospekt, Moscow, 2017.

[7] V.D. Gazman, World Leasing Yearbook - 2017. Issue 38, Euromoney, 2017.
[8] Long-term regional target programme "State support of small and medium-sized enterprises in Krasnodar Krai for 2013-2017". Porta of small and medium-sized enterprises of Krasnodar Krai. http://krasnodar.pmp.gkr.su/registry/program/srf/03,723065/. Accessed June 28, 2018.

[9] V.D. Gazman, Financial leasing, National Research University Higher School of Economics, Moscow, 2003.

[10] J. Mills, Leasing in Europe and the review of international lease accounting, Science and Practice 6(2) (2008) 39-62.

[11] S. Gatti, Project finance in theory and practice: designing, structuring, and financing private and public projects, Academic Press, Burlington, 2012.

[12] V.D. Gazman, The influence of alternative leasing models on financial investment, Issues of Economics 7 (2013) 82-97

[13] N.A. Adamov, Leasing - an effective financial tool, Russian Economic Journal 3 (2012) 28-33.

[14] D. Vakhitov, A. Zamaletdinov, Leasing as a factor of economic growth. Procedia Economics and Finance 23 (2015) 839-845.

[15] Tsang, C. Leung, Asset Finance \& Leasing in China and Hong Kong, PwC, 2014

[16] J. Van Horne, J. Wachowicz, Fundamentals of Financial Management, Pearson Education, 13 (2009) 760.

[17] V.S. Lukashov, L.K. Ulybina, Leasing as an investment tool of modernising Russian economy at the modern stage, Austrian Journal of humanities and social sciences 3-4 (2017) 117-124. DOI: http://dx.doi.org/10.20534/AJH-17-3.4-116-122.

[18] Yan, Leasing and debt financing: substitutes or complements? Journal of Financial and Quantitative Analysis 41 (2006) 709-731.

[19] A.L. Eisfeldt, A.A. Rampini, Leasing, ability to repossess, and debt capacity, Review of Financial Studies 22 (2009) 1621-1657.

[20] Belarusian leasing: 2016 review. Official website of leasing in the Republic of Belarus. https://leasing-belarus.by/wpcontent/uploads/2015/10/belorusskij-rynok-lizinga.-obzor-2016g.pdf. Accessed June 28, 2018.

[21] The volume and dynamics of the leasing market. Official portal of RA Expert Kazakhstan. http://raexpert.kz/researches/leasing_2015/part0/. Accessed June 28, 2018.

[22] V.D. Gazman, Leverage leasing: financing the major investment projects, Economic Journal of Higher School of Economics 17(1) (2013) 130-151.

[23] M.M. Cornett, J.J. McNutt, P.E. Strahan, H. Tehranian, Liquidity risk management and credit supply in the financial crisis, Journal of Financial Economics 101 (2011) 297-312.

[24] T. Beck, A. Demirguc-Kunt, Small and medium-size enterprises: Access to finance as a growth constraint, Journal of Banking and Finance 30 (2006) 2931-2943. 